\title{
Experimental animal models for diabetes and its related complications-a review
}

\author{
Chidhambara Priya Dharshini Kottaisamy @ Divya S. Raj@, V. Prasanth Kumar and Umamaheswari Sankaran* (1)
}

\begin{abstract}
Diabetes mellitus, a very common and multifaceted metabolic disorder is considered as one of the fastest growing public health problems in the world. It is characterized by hyperglycemia, a condition with high glucose level in the blood plasma resulting from defects in insulin secretion or its action and in some cases both the impairment in secretion and also action of insulin coexist. Historically, animal models have played a critical role in exploring and describing malady pathophysiology and recognizable proof of targets and surveying new remedial specialists and in vivo medicines. In the present study, we reviewed the experimental models employed for diabetes and for its related complications. This paper reviews briefly the broad chemical induction of alloxan and streptozotocin and its mechanisms associated with type 1 and type 2 diabetes. Also we highlighted the different models in other species and other animals.
\end{abstract}

Keywords: Diabetes, Complications, Animal models, Alloxan, Streptozotocin

\section{Background}

Diabetes is a chronic noncommunicable diseases (CNCDs) [1] characterized by chronic hyperglycemia resulting from defects in secretion and action of the pancreatic hormone insulin [2]. It is a group of metabolic diseases and considered as a leading global health problem [3]. In general, diabetes mellitus is categorized into type 1 , type 2 and gestational diabetes based on the etiology and clinical features [4]. Type 1 diabetes was recently named adolescent diabetes or insulin-subordinate mellitus diabetes [5], a condition caused by the destruction of pancreatic $\beta$-cells by $\mathrm{T}$ cells resulting in a complete insulin deficiency [6]. Type 1 disease represents $5-10 \%$ of patients with diabetes [7]. Type 2 diabetes also known as adult onset diabetes or non insulin dependent diabetes is characterized by insulin resistance and relative insulin deficiency [8] and is the most prevalent form of diabetes accounting for at least $90 \%$ of all cases of diabetes [9].

*Correspondence: umamsu@gmail.com

Department of Biotechnology, Manonmaniam Sundaranar University, Tirunelveli 627 012, Tamil Nadu, India
Gestational diabetes occurs during pregnancy in women [10]. The fact behind this type of diabetes is that women with gestational diabetes are at an increased risk of developing type 2 diabetes later in their life [11]. The major cause for type 1 diabetes is believed to be a combination of genetic predisposition and additional environmental factors [12]. Type 2 diabetes is mainly caused due to insulin resistance [13]. Obesity is one of the leading causes for diabetes [14]. About $90 \%$ of the people with type 2 diabetes are obese [15]. Diabetes can also be caused due to damages to the pancreas [16] and also due to some rare genetic forms [17]. Diagnosis at an early stage and controlling blood sugar, blood pressure and cholesterol can prevent or delay the complications associated with diabetes [18]. The prevalence of diabetes in the Asian countries is higher particularly in India and China [19]. These two countries were ranked in the top two with 109.6 million and 69.2 million diabetics respectively [20]. In developed countries, about $10 \%$ of their budget for health care is utilized for the management of diabetes [21]. It has been predicted that the prevalence of diabetes mellitus will reach up to 642 million by the year 2040 
globally [22]. Since diabetes imposes serious threat to individual's health and causes societal economic burden [23], research on its management and treatment is now one of the most sought area of interest. In general, animal model study is essential for the development of new and effective means of treating diseases like diabetes. A number of animals are exploited for the experimental studies related to diabetes since animals are biologically similar with humans. Some of the animals employed in diabetes research and the methods of induction of diabetes in the animals are discussed below. The review also highlights the experimental animals employed for studying the diabetes related complications such as diabetic peripheral neuropathy, diabetic nephropathy and diabetic cardiomyopathy.

\section{Main text}

\section{Animal models}

In general, experimental diabetes mellitus is instigated in animals [24], because animal models plays an effective role in understanding the pathogenesis of the disease [25]. Even though a number of in vitro and in silico studies are available and are improved in the last decades, animal models still remains the effective one in understanding the complex etiology and multi-systemic interactions present in diabetes [26]. Many of the diabetes trials are performed in rodents while some studies are also done in larger animals. The experimental animal used in the study of diabetes mellitus can be categorized into three types such as genetically diabetic animals, miscellaneous models and other models based on the methods to induce experimental diabetes mellitus [27]. Diabetes can be developed in the experimental animals either by spontaneous methods or by using chemical agents [28]. Animal models may be developed by two principal mechanisms: disease induction (e.g., using specific drugs) or genetic manipulation. Both are of significant as they enable the analysis of particular mechanisms related to the disease and are important for understanding the pathogenesis and progression of the disease and extrapolating to humans. Since T1DM and T2DM are metabolic disorders that reflect complex integration of body systems, careful consideration is needed in choosing the correct animal model to be used in different in vivo experiments [29]. To achieve this goal, a careful analysis of the specific aspects of the disease and the specific knowledge that is targeted in each study must be performed when choosing a diabetes mellitus animal model [30]. The experimental animal models are classified based on the type of diabetes actually it mimics and also the mode of induction such as spontaneous or induced [26,31]. Since T1DM is characterized by the deficiency of insulin production, the deficiency is achieved in experimental animals through chemical destruction of pancreatic $\beta$-cells or through breeding of rodents that spontaneously develop autoimmune diabetes. Onthe other hand, T2DM animal models are more numerous and may embrace obese and nonobese models with variable insulin resistance and $\beta$-cell failure degrees. In addition, there are transgenic and take out mouse models accessible, however their utilization in the examination field is as yet questionable [30].

\section{Mice and rats}

Mice as an experimental animal have made enormous contributions to our understanding of human biology [32]. Mouse models are extensively exploited for studying the human disease because of the genetic homology between the two species [33]. The mouse models are extensively used to understand the basic knowledge of the human disease and the acquired knowledge progresses to preclinical investigations with the same mouse models [34]. With respect to diabetes, the mouse models are an invaluable one in obesity and type 2 diabetes experimental studies to identify the role of inflammation, insulin resistance, other potential treatments and the knowledge acquired from such studies are faithfully been carried out in humans diagnosed with such disease [35]. The rat as an experimental animal model of human disease offers various favourable circumstances and advantages over the mouse and different species [36]. The physiology in the rodent is simpler to follow and after some time an amount of information has developed which will take a very long time to recreate in the mouse [37]. Rat is extensively used as a suitable animal model for understanding the metabolic profile and pathology involved in different stages of type 2 diabetes [38]. A number of experimental mice and rat models are employed in the study of diabetes (Table 1) and are discussed below.

\section{Chemically induced rat and mice diabetic models}

Some chemicals are used to induce diabetes in the experimental animals. Such chemicals are called as diabetogenic agents. Streptozotocin and alloxan are the commonly used chemical agents that induce diabetes when administered parenterally [39]. Depending on the animal species and route of administration, the dosage of the two drugs may vary [40].

\section{Alloxan induced models}

Alloxan (5,5-dihydroxyl pyrimi-dine-2,4,6-trione) is an organic compound and is a cytotoxic glucose analogue [41] which is used to induce diabetes mellitus chemically by two proposed possible mechanisms [42]. One reports that alloxan specifically inhibits glucose-incited insulin emission by broad glucokinase restraint, the Betacell pancreatic glucose sensor [43] and it also induces 
Table 1 Experimental rat and mice model for type 1 and type 2 diabetes

\begin{tabular}{|c|c|c|c|}
\hline Method of induction & Model animal & Description & References \\
\hline \multirow[t]{2}{*}{ Chemical induction } & Alloxan induced model & Selective inhibition of glucose stimulated insulin secretion & {$[41]$} \\
\hline & Streptozotocin induced model & $\begin{array}{l}\text { Damages the pancreatic } \beta \text { cell thereby causing hypoinsulinemia and } \\
\text { hyperglycemia }\end{array}$ & [164] \\
\hline \multirow[t]{5}{*}{ Spontaneous auto immune } & NOD mice & $\begin{array}{l}\text { Polygenic model of Type } 1 \text { Diabetes characterized by hyperglycemia and } \\
\text { leukocytic infiltration of the pancreatic islet of Langerhans }\end{array}$ & [11] \\
\hline & BB rats & $\begin{array}{l}\text { Spontaneously develop hyperglycemia and ketoacidosis that character- } \\
\text { ize the clinical onset of Type I Diabetes }\end{array}$ & {$[11]$} \\
\hline & KDP rats & $\begin{array}{l}\text { Spontaneous animal model with nonsense mutation in the } \mathrm{Cblb} \text { and is a } \\
\text { model of autoimmune type } 1 \text { diabetes }\end{array}$ & {$[68]$} \\
\hline & LETL & $\begin{array}{l}\text { Spontaneously developed autoimmune diabetes model without lym- } \\
\text { phopenia }\end{array}$ & {$[67]$} \\
\hline & LEW-iddm & $\begin{array}{l}\text { Spontaneously develops insulin dependent autoimmune diabetes } \\
\text { through pancreatic } \beta \text { cell apoptosis }\end{array}$ & [11] \\
\hline \multirow[t]{5}{*}{ Genetically induced } & AKITA mice & $\begin{array}{l}\text { Genetically induced monogenic model that develops insulin dependent } \\
\text { diabetes }\end{array}$ & [11] \\
\hline & Zucker Diabetic Fatty rats & $\begin{array}{l}\text { Developed with missense mutation in the leptin receptor gene. It } \\
\text { develops obesity without diabetes and is used in the study of type } 2 \\
\text { diabetes }\end{array}$ & [165] \\
\hline & $\mathrm{db} / \mathrm{db}$ & $\begin{array}{l}\text { Diabetic model of type } 2 \text { diabetes having a mutation in the gene encod- } \\
\text { ing leptin receptor }\end{array}$ & [165] \\
\hline & GK rats & $\begin{array}{l}\text { Polygenic model that develops adult onset type } 2 \text { diabetes earlier in } \\
\text { their life }\end{array}$ & [166] \\
\hline & Zucker fatty rats & $\begin{array}{l}\text { Genetic obese model characterized by hyperlipidaemia and hypoinsu- } \\
\text { linemia }\end{array}$ & [167] \\
\hline \multirow[t]{2}{*}{ Genetically engineered } & KK mouse & $\begin{array}{l}\text { Polygenic diabetic model that exhibit type } 2 \text { diabetes associated with } \\
\text { hyperglycemia, glucose intolerance and microalbuminaria }\end{array}$ & [168] \\
\hline & Obese hyperglycemic mice & $\begin{array}{l}\text { Used as Obesity model since these are overweight and hyperphagic } \\
\text { from its young age and lack functional leptin }\end{array}$ & [167] \\
\hline Surgical & Pancreatectomy model & $\begin{array}{l}\text { Resemble type } 2 \text { diabetes since pancreatic beta cell mass gets reduced } \\
\text { when certain percentage of pancreas is removed }\end{array}$ & [169] \\
\hline \multirow[t]{2}{*}{ Virus induced } & Coxsackie B virus induced model & $\begin{array}{l}\text { Develops insulin dependent diabetes mellitus as a result of re stimula- } \\
\text { tion of resulting auto reactive T cells }\end{array}$ & {$[170]$} \\
\hline & EMC virus induced model & Develops Diabetes mellitus by selective destruction of $\beta$ cells & {$[171]$} \\
\hline
\end{tabular}

reactive oxygen species (ROS) formation, creating a redox cycle generating superoxide radicals [44]. Alloxan is decreased to dialuric corrosive and then re-oxidized back to alloxane, making superoxide radicals that experience dismutation (by superoxide dismutase) to form hydrogen peroxide; side responses can likewise make hydroxyl radicals. These highly reactive oxygen species may cause $\beta$-cell DNA fragmentation leading to apoptosis $[11,43,45]$. While alloxan is additionally taken up by the liver, alloxan-prompted hepatotoxicity is insignificant or invalid on the grounds that the liver has more productive ROS safeguard instruments than $\beta$-cells [45] and they also have several mechanisms for xenobiotic biotransformation and elimination. Alloxan additionally advances basic oxidation-SH classes, particularly glutathione (GSH) compounds, proteins and likewise dysregulates intracellular calcium homeostasis bringing about centralizations of supraphysiological calcium and consequently cell harm [11, 45]. Dosages of alloxan extend from 50 to $200 \mathrm{mg} / \mathrm{kg}$ (in mice) and from 40 to $200 \mathrm{mg} /$ $\mathrm{kg}$ (in rodents), contingent upon the strain and course of organization picked (e.g., intraperitoneal and subcutaneous organization of alloxane requires portions up to multiple times the intravenous organization [11].

\section{Streptozotocin induced models}

Streptozotocin (STZ), chemically known as N(methylnitrosocarbamoyl)- $\alpha$ - $d$-glucosamine is a naturally occurring compound produced by Streptomycetes achromogenes with antibacterial properties [46] that are selectively taken up by pancreatic $\beta$-cells causing its destruction [47]. It is also a cytotoxic glucose analogue [43] like alloxan. Rakieten reported the use of STZ as a diabetogenic [48]. The STZ is the most commonly used chemical for the induction of diabetes mellitus in the experimental animals [49]. It is a nitrosourea compound [50] with a toxic glucose and a $\mathrm{N}$-acetyl glucosamine analogue that gets accumulated in the pancreatic $\beta$ cells 
through the GLUT-2 (a transmembrane carrier protein) transporter uptake [51]. STZ induce diabetes rats, mice and other animals like rabbit and guinea pigs through two ways depending on the dose [52]. At high dose, STZ targets pancreatic $\beta$ cells by its alkalyting property which is a normal function of the cytotoxic nitrosourea compounds [53]. In general, the nitrosourea compounds are lipophilic in nature and hence are easily uptaken by the cells, but in contrast the STZ being a nitrosourea compound is hydrophilic due to hexose substitution and are not easily uptaken by the cells thereby STZ is carried by a carrier protein of Glucose called GLUT- 2 to the $\beta$ cells because the chemical structure of the STZ resembles glucose moiety [54]. The $\beta$ cell of the pancreas usually have selective properties of the STZ and hence the chemical compound keep $\alpha$ cell of the pancreas and the extra pancreatic cells in an intact condition and do not affect it [43]. It is the same in case with humans where STZ do not affect any of the pancreatic cells including $\beta$ cell [46]. At low doses (usually given as multiple exposure), STZ induce immune and inflammatory response which is due to the release of the enzyme glutamic acid decarboxylase [55]. This enzyme is a major auto antigen in autoimmune diabetes [56]. When released from the islet $\beta$ cell, the enzyme comes in contact with the immune effector cells [57]. This condition aids in the destruction of $\beta$ cell and leads to the development of hyperglycemic state that is associated with inflammatory infiltrates in particular with lymphocytes of the pancreas [55]. In the high-portion STZ technique, a solitary portion of STZ is directed to mice by means of intravenous or intraperitoneal routes $(100-200 \mathrm{mg} / \mathrm{kg})$ or rats $(35-65 \mathrm{mg} / \mathrm{kg})$ producing massive pancreatic $\beta$-cell destruction with little or no insulin production [58]. Various low-portions STZ technique suggests that little dosages ( 20 to $40 \mathrm{mg} / \mathrm{kg} /$ day) ought to be directed over some undefined time frame to advance insulitis [11, 59].

\section{Spontaneous auto-immune rodents and mouse}

NOD-mouse, diabetes prone BB rats, KDP rat, LETL rat and LEW-iddm rat are the widely used animal models of spontaneous diabetes for studying the autoimmune diabetes [28]. Nonobese diabetic (NOD) mouse is one of the most regularly utilized models for investigations of type 1 diabetes (T1D). This is due to the fact that NOD mouse resembles a number of genetic and immunological traits with the human form of the metabolic disorder [60]. Dissimilar to different models utilized in autoimmunity examines, this model can build up a comparative unconstrained sickness to humans. Utilization of this model has prompted a few advances in understanding the illness including recognizing a few auto antigens and biomarkers that are comparative in people and have empowered the development of therapeutic targets [61]. This NOD mouse originated in the interbreeding of Cataract Shionogi (CTS strain) expressed polyuria, glycosuria and lymphocytic infiltration in the islets of langerhans region of the pancreas [62]. The greatest hereditary factor adding to T1D defenselessness in both NOD mice and humans is the major histocompatibility complex $(\mathrm{MHC})$. Like humans, many genes in the NOD mice are also susceptible to develop type 1 diabetes. The MHC alleles play an important role in the development of the disease. In humans and NOD mouse, the combined action of many MHC alleles with the non-MHC genes results in their diabetogenic action $[28,63]$. The BB rats are the most valuable experimental animals for studying the genetic basis of type 1 diabetes [64] and also in intervention studies $[65,66]$. This sort of rodent had been derived from the outbred Wistar rodents in which spontaneous hyperglycemia and ketoacidosis occurred in the 1970s period. From such affected rodents, two colonies were found that serves as the base for the establishment of all other $\mathrm{BB}$ rat colonies including one ingrained biobreeding diabetes-prone/worceste (BBDP/Wor) and one outbred biobreeding diabetes-prone (BBDP) rodent $[67,68]$. Biobreeding (BB) rodents create diabetes after adolescence with a comparable rate among males and females with roughly $90 \%$ of rodents creating diabetes somewhere in the range of eight and seventeen years old. The diabetic phenotype is very serious and is portrayed by the improvement of hyperglycemia, hypoinsulinemia weight reduction and ketonuria [11]. Despite the fact that these animals have insulitis with T-cells, B-cells, macrophages and natural killer (NK) cells, they are lymphopenic with extreme decrease in $\mathrm{CD} 4^{+} \mathrm{T}$ cells and close nonattendance of $\mathrm{CD} 8^{+} \mathrm{T}$ cells. Lymphopenia is certainly not a quality of type 1 diabetes (T1D) either in people or Nonobese diabetic (NOD) mice [68]. The Komeda diabetes-prone (KDP) rat is one of the best spontaneous animal model of autoimmune type 1 diabetes disorder studies [69]. It is also an important experimental model in the study of autoimmune disorders in particular autoimmune thyroid disease [70]. Autoimmune destruction of pancreatic $\beta$ cells and rapid onset of diabetes irrespective of age and sex difference and no significant T-lymphopenia are the phenotypic characterization of the KDP rats. The characteristic features are closely similar with human type 1 diabetes [71]. The KDP rats are associated with lymphocyte infiltration and most of the animals exhibit moderate to severe level of lymphocyte infiltration into the pancreatic islets (insulitis). About $80 \%$ of the animals develop diabetes within 220 days of their age [71]. The genetic analysis of type 1 diabetes in the KDP rats showed the genetic predisposition of diabetes which was explained by the two susceptible loci such as major 
histocompatibility complex (MHC) on chromosome 20 and IDDM/ KDP 1on chromosome 11 [72]. Later, Cblb was identified as a major susceptibility gene for type 1 diabetes of rat [70, 73]. The Long Evans Tokushima Lean (LETL) rats are one of the widely used spontaneous animal models of insulin dependent diabetes mellitus (IDDM) since it closely resemble the pathology of human IDDM [74]. These LETL rats were discovered in 1982 and originated from some pairs of outbred Long-Evans rat purchased from Charles river in Canada [75]. The phenotypic characterization of the LETL rats includes 1 . Sudden onset of polyuria, polyphagia, hyperglycemia and weight loss. 2. Lymphocyte infiltration into the pancreatic islets (insulitis) which is followed by the destruction of $\beta$ cells of the pancreas and at the onset of diabetes, the lymphocyte gets disappeared. 3. Lymphocyte infiltration into the salivary gland and lacrimal gland. 4 . Severity of the disease irrespective of the age and gender difference. 5. Hyperplastic foci of pancreatic islets. 6. No significant lymphocytopenia. 7. Renal complications that include nodular lesions [27, 75, 76]. These characteristics are shown to be closely associated with human IDDM. The animals develop hyperglycemia after 18 weeks of their birth [27]. Genetic analysis of the animal showed that two recessive genes are necessitated in the pathogenesis of insulitis [74]. The LEW-iddm rodent model for diabetes (T1D) emerged spontaneously in a colony of Lewis congenic rodents portrayed by a characterized MHC Lewis.1AR1 (LEW.1AR1) haplotype. It is one of a widely used model for examining human type 1 diabetes T1D. These rodents obviously create diabetes between the ages of 60 and 90 days and are described by fast movement of insulitis prompting broad $\beta$ cell destruction [77-79]. This animal develops type 1 diabetes through two modes with different rates of incidence. It develops autoimmune diabetes spontaneously at a rate of $2 \%$ (approximately) and through immunological perturbation at a rate that can reach a maximum of $100 \%$ [80]. This experimental rodent model develops diabetes with equal frequency in both male and females. This unique characterization differentiates it from other spontaneously induced models for studying type 1 diabetes [81]. The genetic analysis of the animal showed an autosomal recessive mode of inheritance for the diabetes inducing genes and it routes a path for the detailed characterization of the loci conferring diabetes [82].

\section{Genetically induced diabetes models}

AKITA mice, GK rats, Zucker diabetic fatty rats, Obese spontaneously hypersensitive rat (SHR), ESS rats and diabetes mouse $(\mathrm{db} / \mathrm{db})$ falls under the category of genetically induced diabetes models. Of them, the most widely used genetically induced diabetic mouse models is AKITA mice. These mice have Ins2+/C96Y mutation which induce an irregular insulin folding and destruction of $\beta$ cells [83, 84]. Initially, the Akita mice were originated on the C57BL/6 inbred strain in Akita, Japan. But these experimental animals were nowadays developed with various genetic backgrounds and are made commercially available in the market. This model involves chronic stress on protein processing involving the endoplasmic reticulum and unfolded protein response triggering apoptosis and diabetes. The unfolded protein response tries to compensate and reduce the protein load of the endoplasmic reticulum, increasing its folding capacity [85]. This leads to toxicity in pancreatic $\beta$ cells, decreasing their insulin secretion. A significant raise in the glucose level and albuminuria is witnessed in 4 weeks of its age and albuminuria tends to increase at a higher rate during the 10th week. Hence are employed in the study of diabetic related complications. The Goto-Kakizaki (GK) rats are insulin-resistant and are non-obese. GK rodents are profoundly acquired strain of Wistar rodents which create type 2 diabetes immediately [86]. It is a genetic experimental model of type 2 diabetes and its related complications [87-89]. It develops peripheral insulin resistance after 56 days of their birth. It has decreased pancreatic $\beta$ cells and its functions [90]. Disease progression of this rat is been associated with chronic inflammation and hence utilized in the study of pathophysiology and therapeutic studies of type 2 diabetes [91, 92]. The Zucker diabetic fatty (ZDF) rats are a type of experimental animal model that reflects type 2 diabetes of human form. These rats originated from a colony of outbred zucker rats in Walter Shaw's laboratory in Indianapolis (USA). Genetic model of the zucker diabetic rat was established in 1991. Insulin resistance, hyperphagia and obesity occur in this animal as a result of spontaneous mutation of a simple autosomal recessive leptin receptor gene (fa) on chromosome 5 [93-96]. ZDF male rats are most widely employed for the study of type 2 diabetes and its progression from prediabetic to diabetic state [97]. The Obese spontaneously hypersensitive rat (SHR) is formed as a result of mutation and it exhibits genetic obesity, endogenous hyperlipemia and other metabolic abnormalities. This strain is formed by mating an unconstrained hypertensive female rodent of the Kyoto-Wistar strain with a normotensive Sprague-Dawley male. These models are widely employed for the study of relationship between endocrine and metabolic abnormalities to obesity. It is considered as an important animal model for the study of role of high blood pressure and hyperlipemia associated with the pathogenesis of arthrosclerosis $[98,99]$. ESS rat (e Stilman Siagado) is an inbred rat line that is maintained in the school of medicine, Rosario University, Argentina. It is an experimental rat variety 
that develops mild diabetic syndrome that is not associated to obesity [100]. The animals experience unpredictable proportions of glucose resistance from 2 months old enough on. The condition is a gentle form of diabetes that doesn't reduce the life expectancy of animals. Half year old rodents exhibited pulverization of islet engineering and stroma fibrosis [101]. The diabetes mouse $(\mathrm{db} / \mathrm{db})$ is formed due to autosomal recessive mutation in the leptin receptor and is originated from the Jackson laboratory. The mutation occurs is a Gly to Thr mutation in the leptin receptor gene on chromosome 4. These animals are obviously obese which is evident from its 3-4 weeks of age, hyperglycemic which is usually observed during 4 to 8 weeks of its age and most importantly hyperphagic (excessive appetite) [102, 103]. An extreme diabetic condition happens in these mice and is described by the beginning stage of hypoinsulinemia and hyperglycemia. Leptin receptor changes bring about a broad phenotype indistinguishable from that of $\mathrm{Ob}$ mice. The leptin receptor (Ob-R) encodes five option joined forms, in particular $\mathrm{Ob}-\mathrm{Ra}, \mathrm{Ob}-\mathrm{Rb}, \mathrm{Ob}-\mathrm{Rc}$ and $\mathrm{Ob}-\mathrm{Rd}$. The Ob-Rb transcript contains a supplement with an untimely stop codon in the C57BL/KsJ ob/ob mouse strain if the grafting is unusual [94].

\section{Genetically engineered diabetic mice}

The genetically engineered diabetic mice include KK mouse and Obese hyperglycemic mice. The KK mouse is widely exploited for investigating the obesity-associated diabetes. The characteristic features of this mouse include moderate obesity, polyphagia and polyuria. The diabetic state of the KK mouse is found to be chemical diabetes since it showed glucose intolerance and insulin resistance but is not glycosuric and hyperglycemic [104]. The KK mouse has the capability to develop type 2 diabetes in response to high fat diet and aging [105]. Hereditarily fat mice (Obese hyperglycemic mice) were recognized by Bleisch et al. as having acquired diabetes. These mice are glycosuric, the level of non-fasting blood sugar is about $300 \mathrm{mg}$ percent, but there is no ketonuria or coma [106]. Insulin resistance is one of its most interesting features. The langerhans islands are hypertrophic with increased insulin content. The diabetes condition of the human diabetic patient is obviously not quite the same as that of the hyperglycemic mice. Halaas et al. detailed that leptin substitution totally inverts the phenotype of obesity and diabetics [107].

\section{Surgical models}

These models are widely employed for the study of regenerative capability of $\beta$ cells or its progenitors. Partial pancreatectomy which involves the partial or total removal of pancreas through surgery is the model that are of greater importance for the study of diabetes. Removal of $95 \%$ of the pancreas causes diabetes in rat models within 3 months and a similar mechanism is found in dogs and pigs. But the fact is that $60 \%$ partial pancreatectomy does not cause increased blood glucose concentrations and a moderate increase in the $\beta$ cell mass level is only witnessed [108]. About $90 \%$ pancreatectomy elicits moderate hyperglycemia which is later followed by the pancreatic regeneration [109]. The major drawback of this model is invasiveness (especially to healthy tissues rather than pancreas) which makes it technically insignificant [11].

\section{Virus induced models}

Viruses cause diabetes mellitus through the degradation and infection of $\beta$ cells in the pancreas. Numerous human infections used to actuate diabetes incorporate RNA picornoviruses, coxsackie B virus [110], kilham rat virus [111] and encephalomyocarditis virus (EMC) [112]. CVB4 (coxsackie virus B4) is the most predominantly found enterovirus in the diabetic individuals. The CVB strain isolated from pancreas of a diseased child diagnosed with diabetic ketoacidosis induce diabetes in murine cells when inoculated into it [113]. Coxsackie virus is associated with the development of insulin dependent diabetes mellitus. EMC-D virus can infect and destroy beta-cells of the pancreas in mice and cause hyperglycemia dependent on insulin. A clone of EMC virus is identified as NDK2. Intraperitoneal injection of NDK25 develops non insulin dependent diabetes mellitus [114].

\section{Other species with inherited diabetes symptom Chinese hamster}

Meier and Yerganian [114] described the occurrence of hereditary diabetes mellitus in the Chinese hamster (Cricetulus griseus). Diabetic hamsters have increased levels of blood sugar from a typical $110 \mathrm{mg}$ to $600 \mathrm{mg}$ each. Extreme polyuria, glycosuria, ketonuria, and proteinuria are the diabetic symptoms found in Chinese hamsters. Diabetic symptoms could be improved by administering insulin and oral antidiabetic drugs. Sections of the pancreas, liver and kidney show historically pathological changes. The number of pancreatic islets is decreasing and the remaining islet cells are abnormal [115].

\section{TUCO-TUCO}

Shrewd et al. detailed that the diabetic disorder in TucoTucos (Ctenomys talarum) to be similar to sand rodents and prickly mice. Tuco-Tucos, however tend to be less hyperglycemic and are less prone to ketosis. Many animals mainly males become hyperphagic. The usual lesion in the pancreas is degranulation of $\beta$ cell in few animals, 
but amyloid islet hyalinization has also been observed [116].

\section{Sand rat}

The sand rat (Psammomys obesus) lives in the north African and near east desert regions [117]. This rat model is used for studying the effects and consequences of diet and exercise in the development of type 2 diabetes [118]. The animals create diabetic side effects when fed up with laboratory chow rather than a full vegetable eating routine [119]. The diabetic disorder for the most part creates in sand rodents in 2-3 months. Truly hyperglycemic animals bite the dust rashly from the ketosis. These animals develop hyperlipidaemia and arthrosclerosis when fed up with cholesterol rich diet [120].

\section{Spiny mouse}

The spiny mouse (Acomys cahirinus) occurs in the eastern Mediterranean semi-desert areas. Under laboratory settings, diabetes occurs in around 15 per cent of animals. Diabetes is caused by endocrine-pancreatic hyperplasia. Some animals have obesity, moderate hyperglycemia and hypoinsulinemia and others have explicit glucosuric hyperglycemia that leads to fatal ketosis. Characteristically, all spiny mice have massive pancreatic islet hyperplasia and increased pancreatic insulin content [121].

\section{African hamster}

The spontaneous diabetes mellitus in the African hamster (Mystromys albicaudatus) is first described by Schmidt et al. The characteristic features of this species include hyperglycemia, polyuria, polyphagia, polydipsia, glucosuria, ketonuria and pancreatic lesions including $\beta$-cell vacuolization, glycogen infiltration, nuclear pycnosis, margination of organelles and $\beta$-cell death [27].

\section{Non rodent-diabetes models} Invertebrate animal model-Bombyx mori

A mammalian model can be replaced with an invertebrate animal model to overcome the problems associated with modern animal rights so that it can reduce the mortality rate of mammals [122]. Silkworms are established as an animal model for life sciences since it contains a number of genes that are homologous to humans. Besides this, the silkworm is moderately sized organisms that can be dissected easily. This feature enables the broad availability of silkworm as a model to perform oral administration and intravenous injection examination studies [123]. In humans, adenylate protein kinase signalling pathway is responsible for the regulation of blood glucose and the same signalling pathway also regulates hemolymph glucose levels in silkworm. Moreover, the insulin like peptide that is encoded by the genes of the silkworms shows
$40 \%$ similarity with that of human insulin. These two features aid in the development of silkworm as a model for diabetes. This can be achieved through the expression of human insulin receptor (hIR) in transgenic silkworm [124].

\section{Pigs as diabetic model}

Pigs are employed as an excellent model for the study of diabetes and its related complications. It is because of the fact that the morphology of the pancreas of the pig and its overall metabolic status are similar with that of humans. The Yucatan pig is originally from Mexico's Yucatan Peninsula. The early origination and characterization of the animal occurred at Colorado State University. Reportedly, selective breeding is an effective method for raising pigs with reduced glucose tolerance [125]. Recently a yucatan mini pig model of diabetic dyslipidemia at the University of Missouri at Columbia has been described in which alloxan (175 mg/kg intravenously) was given to induce diabetes [126]. These pigs are found to have a normal number of islets of langerhans and $\beta$ cells and also have normal insulin release in response to isoproterenol challenge.

\section{Primate model-obese Rh monkey}

Rhesus monkey as an experimental model for diabetes is initially described by Hansen et al. where the monkeys are classified into sequential phases of the metabolic disease based on some parameters like age, body weight, glucose tolerance, fasting insulin levels and secretory insulin levels. The heterogeneity of plasma insulin and blood glucose level is identified as sequential changes that show the development of impaired glucose tolerance and type 2 diabetes. Once the monkey become diabetic, an abundant level of islet amyloid formed sequentially [127]. Rhesus monkey fed up with a high fructose diet is found to produce insulin resistance, obesity and inflammations within a short span of time and finally develops type 2 diabetes [128]. The rhesus and cynomolgus monkeys are identified as useful animal models for investigating the effects of therapeutic arbitrations as a result of preclinical islet transplantation studies [129].

\section{Zebra fish models}

Nowadays, zebra fish is widely employed for diabetes research. It is an attractive model system to study the metabolic disorders and is also used to identify and develop treatment for such disorders. The zebra fish possess conserved cholesterol metabolism and energy homeostasis. These key features make them an ideal model for the study of lipid metabolism [130]. Moreover, the zebra fish have a well developed organ system like digestive system, skeletal muscle and adipose tissue similar to that 
of humans and hence are mostly utilized for the clinical studies [131]. The zebra fish when fed up with excessive nutrients is found to develop increased plasma triglyceride levels and are found to develop hepatic steatosis [132]. It is also used in the therapeutic studies of diet induced glucose intolerance and insulin resistance. The zebra fish possess high human genetic homology that aids in the exploitation of it for the study of metabolic syndromes. Because of the availability of its fully sequenced genome, easier genetic manipulation and higher fecundity rates, the zebra fish are established as a unique model for the study of metabolic disorders of humans [133].

\section{Diabetic complications}

Hyperglycemia, a condition characterized by high level of glucose in the blood is a characteristic feature of both type 1 and type 2 diabetes. Because of its subtle and chronic nature, the hyperglycemia plays a key role in the development of diabetic complications [134]. The complications associated with diabetes are categorized into two such as micro vascular which occurs when there is any damage to the blood vessels and macro vascular disease that usually occurs due to damage to arteries. It is found that the underlying mechanism behind the pathogenesis of such diabetic complication is oxidative stress that is formed by the overproduction of reactive oxygen species (ROS) [135]. It may also be due to any defects in the insulin signal transduction pathway that is a key pathway involved in maintaining glucose homeostasis. A bioactive sphingolipid called ceramide is found to have an inhibitory effect over such pathway and may lead to complications [136]. The complications related to diabetes include neuropathy, nephropathy, retinopathy and cardiovascular diseases [137]. A number of animal models are employed for investigating the diabetic complications (Table 2) and are discussed below.

\section{Diabetic neuropathy}

Diabetic neuropathy is characterized by peripheral nerve dysfunction especially in type 2 diabetic patients. About two third of diabetic patients are having clinical or subclinical diabetic neuropathy complication [138]. A downstream metabolic cascade that is usually formed as a consequence of chronic hyperglycemia leads to the peripheral nerve dysfunction in diabetic patients. The cascade may be formed through an increased flux of the polyol pathway that metabolize the unused glucose in the presence of enzymes and hence is an enzymatically driven pathway. Excessive release of cytokines, activation of protein $\mathrm{C}$ kinase and overstate oxidative stress that occurs as a result of hyperglycemia are also key features

Table 2 Experimental animal models for diabetic complications

\begin{tabular}{|c|c|c|c|}
\hline Diabetic complications & Animal Model & Characterization & References \\
\hline \multirow[t]{5}{*}{ Diabetic neuropathy } & STZ induced rat model & $\begin{array}{l}\text { Reduced fibre size of the peroneal nerve and axon than that of the myelin } \\
\text { sheath with impaired motor function }\end{array}$ & [139] \\
\hline & C57BL/KS (db/db) mice & $\begin{array}{l}\text { Decreased sensory nerve conduction velocity and density of intraepider- } \\
\text { mal nerve fibers (IENF) }\end{array}$ & {$[140]$} \\
\hline & Ischemic reperfusion injury model & $\begin{array}{l}\text { Decreased serum IL-10 level and nerve conduction velocity and nerve } \\
\text { fibre density }\end{array}$ & [141] \\
\hline & Chinese Hamster & Reduced conduction velocity & {$[142]$} \\
\hline & Obese Rh Monkey & Reduced conduction velocity and prolonged duration of F-wave latencies & {$[143]$} \\
\hline \multirow[t]{5}{*}{ Diabetic nephropathy } & NOD mice & Enlarged glomeruli and mesangial sclerosis & {$[146]$} \\
\hline & C57BL/6 & Albuminuria and reduced renal functions & {$[147]$} \\
\hline & GK rat & Thickening of glomeruli leading to glomerular hypertrophy & {$[148]$} \\
\hline & Zucker diabetic fatty rat & Glomerulosclerosis, tubulointerstitial fibrosis and renal hypertrophy & [149] \\
\hline & Zebra fish & Over expression of CIN85/RukL causing edema & {$[150]$} \\
\hline \multirow[t]{5}{*}{ Diabetic retinopathy } & Alloxan induced model & Microaneurysms with increased acellular capillaries & {$[153]$} \\
\hline & Akita mice & Decreased number of amacrine and ganglion cells & {$[154]$} \\
\hline & $\mathrm{db} / \mathrm{db}$ mouse & Reduced number of Retinal ganglion cells with thickened retina & {$[153]$} \\
\hline & Surgical model & Formation of proliferative and contractile cellular membranes in the retina & [155] \\
\hline & Zebra fish & Degradation and thinning of retina & {$[156]$} \\
\hline \multirow[t]{5}{*}{ Diabetic cardiomyopathy } & Alloxan induced model & Formation of advanced glycation end products leading to oxidative stress & {$[158]$} \\
\hline & BB rats & Reduced calcium — stimulated ATPase activity and cardiac contractility & {$[159]$} \\
\hline & OLETF rats & Alteration in left ventricular diastolic function & {$[161]$} \\
\hline & STZ induced model & Fibrosis and apoptosis leading to myocardial damage & {$[162]$} \\
\hline & GK rats & Hyperglycemia, hyperlipidaemia and cardiac cell death & [163] \\
\hline
\end{tabular}


behind the development of peripheral nerve dysfunction [139].

\section{Animal models for diabetic neuropathy}

STZ induced rat model is used in the study of diabetic neuropathy. With the induction of STZ in rat, the fibre size of the peroneal nerve along with the axon size gets reduced twice than that of the myelin sheath. These changes lead to the understanding of motor conduction velocity found in diabetics and hence are utilized in investigating the development, progression and therapeutic options of diabetic neuropathy [140]. The C57BL/ $\mathrm{Ks}(\mathrm{db} / \mathrm{db})$ mice model is extensively used in the study of diabetic neuropathy. This model develops symptoms like decreased sensory nerve conduction, velocity and density of intraepidermal nerve fibers (IENF) also gets reduced when fed up with a high fat diet (24\% fat, $24 \%$ protein and $41 \%$ carbohydrates) for a period of 12 weeks. These symptoms showcase the onset of diabetic neuropathy and hence these models are exploited for investigating the onset and progression of diabetic neuropathy [141]. Muthuraman et al. showed that animal model developed of ischemic-reperfusion injury inducednociceptive sensory neuropathy is effective in the study of pathophysiological mechanisms involved in the development of neuropathic pain because the model showed a decreased serum IL-10 level and nerve conduction velocity that is similar with humans [142]. The Chinese hamster are also well utilized in the study of diabetic neuropathy since it shows a reduction in the conduction velocity when diabetes is induced and such reduction is similar with the condition of diabetic neuropathy in humans [143]. The obese Rhm monkey model is exploited to understand the pathogenesis and therapeutic options of diabetic neuropathy since it showed reduced conduction velocity and prolonged duration of F-wave latencies evoked by electrical stimulation of the peripheral motor. Such changes are similar with humans and hence are considered as a primate model of human diabetic neuropathy [144].

\section{Diabetic nephropathy}

Diabetic nephropathy develops in 30 to $40 \%$ of diabetic patients and is due to hyperglycemia and presence of genetic predisposition. Hyperglycemia induces the protein $\mathrm{C}$ kinase activation and increase the production of glycosylation end products. Apart from this, hyperglycemia also stimulates the renal cells (both resident and non-resident) in producing cytokines, growth factors and humoral mediators and causes some structural and functional alterations finally leading to the shear stress. Through these effects, hyperglycemia leads to renal damage and is considered as a major complication of diabetes [145]. Multigenetic predisposition plays as an important role in the development of the complication and hence is called as complex genetic disease and a number of genes are involved in the development of the complication. Apart from genetic factors, epigenetic and environmental factors also play a lead role in the progression of diabetic nephropathy [146].

\section{Animal models for diabetic nephropathy}

A strain of nonobese, non diabetic mice developed together with diabetic strain of NOD mice is found to have spontaneous lipid deposition in the glomerular capillary lumina and also develops features of renal injury including enlarged glomeruli and mesangial sclerosis that are characteristic of human diabetic nephropathy [147]. Progressive albuminuria and vast decrease in renal function which are the characteristic of diabetic nephropathy are observed following induction of Akita mutation in the C57BL/6, DBA/2, and 129/SvEv strains and hence are broadly utilized in the study of diabetic nephropathy [148]. The GK rat model develops changes in the glomeruli (thickening) and tubular basement membrane and also develops glomerular hypertrophy. These features are observed in case of human diabetic nephropathy and hence are widely exploited for elucidating the pathogenesis and examining the novel therapies for diabetic nephropathy [149]. Zucker diabetic rats are also exploited in the study of diabetic nephropathy. As their age progress (week by week), this animal model develops renal hypertrophy and other pathological changes like glomerulosclerosis, tubular cell damage, tubulointerstitial fibrosis and inflammation that resemble the human diabetic nephropathy and therefore ZDF rats are useful rodent model of diabetic nephropathy [150]. Hyperglycemia induced in zebra fish through intraperitoneal injection of STZ develops changes like thickening of glomerular basement membrane and over expression of CIN85/RukL causing edema and disrupts the filtration barrier and so such models are employed for the study of diabetic nephropathy [151].

\section{Diabetic retinopathy}

In diabetic retinopathy also, the hyperglycemia plays an important role. Hyperglycemia is associated with retinal micro vascular damage and aids in the development and progression of diabetic retinopathy. The risk of developing diabetic retinopathy is closely dependent on factors such as blood glucose levels, blood pressure, lipid profiles and also on type and the span of diabetic disorder [152]. Like the above discussed complications, oxidative stress, increased polyol pathway, protein $C$ kinase activation and accelerated formation of glycation endproducts plays a key role in the development of the complication. In addition to the above features, increased expression of 
vascular endothelial growth factor (VEGF), insulin like growth factor-1 (IEF-1) and activation of the renin-angiotensin-aldosterone system (RAAS) also developed as a consequence of hyperglycemia which in turn aids in the development of diabetic retinopathy [153].

\section{Animal models for diabetic retinopathy}

Alloxan is used to induce diabetic retinopathy in rats, mice, pigs and rabbits. It has been studied that alloxan induced mice develop loss of pericyte and retinal ganglion cells (RGCs) within 7 days of induction. The same model develops microaneurysms with increased acellular capillaries. With such broad range of efficiencies, the alloxan induced experimental mice and rats are employed in the investigational study of diabetic retinopathy [154]. Akita mice are employed as a model for early stage of diabetic retinopathy. A significant increase in the vascular permeability is witnessed at 12 weeks after hyperglycemia. At 3 months, the mice also exhibit thinning of the retina, cone loss, disturbance of synaptic connectivity and finally a decrease in the number of amacrine and ganglion cells [155]. Diabetes mouse $(\mathrm{db} / \mathrm{db})$ is exploited for the study of late stages of diabetic retinopathy since it presents reactive gliosis along with leakages of the vessels. The animal model usually shows a reduction in the number of retinal ganglion cells (RCGs) with increased thickness in the central retina of the eye [154]. Apart from that, pig eyes are employed in the research since it closely resembles the size, structure of the retina and vasculature of the human eyes. A model developed through proliferative vitreoretinopathy involving surgical methods and intravitreal injection of retinal pigment epithelial cells is used in the study of diabetic retinopathy [156]. The features like degradation and thinning of retina (aneurism like structure) are observed in high glucose incubation zebra fish models. Hyperglycemias induced in such models are found to have adverse effect on retina of the eye that are similar with humans. With such context, the zebra fish are also employed in the study of diabetic retinopathy [157].

\section{Diabetic cardiomyopathy}

Cardiovascular diseases in particular heart attack are the leading cause of complications in diabetes. The clinical outcome associated with heart failure is higher in patients with diabetes than in non diabetic patients. Diabetic cardiomyopathy is mainly associated with type 2 diabetes. This is due to the fact that incompetence to increase glucose metabolism, incapability in substrate utilization within the diabetic heart formed as a consequence of type 2 diabetes will develop uncoupling of mitochondria, glucotoxicity and lipotoxicity. This sequence of events initiates cardiac dysfunction that includes myocardial fibrosis and steatosis, remodelling of the extra cellular matrix, diastolic dysfunction and finally systolic dysfunction which progressed and finally leads to heart attack [158].

\section{Animal models for diabetic cardiomyopathy}

Alloxan induced diabetic model is employed in the investigation of therapeutic options for treating diabetic cardiomyopathy (DCM). Bhattiet al studied the effect of ethanolic extract of Aegle marmelos (L.) Correa (Rutaceae), a deciduous plant on early stage diabetic cardiomyopathy in alloxan induced diabetic rats. Conditions like hyperglycemia and excess of glucose along with structural alterations in collagen results in the formation of advanced glycation end (AGE) products which inturn cause oxidative stress in the tissue. Since the heart has low levels of free radical scavenging mechanisms, the excessive formation of reactive oxygen species results in the formation of cardiovascular complications in the rat [159]. BB rats are widely used in the study of diabetic cardiomyopathy since it develops lower calcium-stimulated ATPase activity, cardiac contractility and depressed left ventricular developed pressure that are seen during diabetics in humans [160]. Yucatan mini pig, a non rodent animal model is also employed in the study of diabetic cardiomyopathy. The Yucatan mini pig develops obesity and insulin resistance when overfed with western diet. The chemically induced diabetes in pigs are used to study the pathogenesis of cardiovasculopathies [161]. Apart from the above models, the Otsuka Long-Evans Tokushima Fatty (OLETF) rats are now established as a model of diabetic cardiomyopathy. The OLETF rats showed alteration in the left ventricular diastolic function in its prestage of type 2 diabetes with prolonged deceleration time and decreased amplitude of peak velocity of the early diastolic filling wave. These changes occur due to metabolic abnormalities without any difference in their blood pressure and heart rate. Hence the OLETF rats are proposed to be an experimental animal model for the study of mechanism of alteration of heart function [162]. STZ induced type 1 diabetes in spontaneously hypertensive rats (SHR rats) in over term develops myocardial damage characterized by fibrosis and apoptosis. Reduction of proinflammatory factors and reduced expression of antioxidant molecules are found to be responsible for the mechanism behind the damage [163]. With such mechanisms, the STZ induced diabetes models are also used in the study of cardiomyopathy. Untreated GK rats induced with diabetes showed hyperglycemia, hyperlipidaemia and finally cardiac cell death in its progressive stage and hence are also employed in the study of diabetic cardiomyopathy [164]. 


\section{Conclusions}

A number of type 1 and type 2 diabetic animal models and models employed for studying the diabetic complications were described above. Each differs in their characteristic and the development of the disorder. The experimental models are widely employed in studying the pharmacology and mechanisms underlying the metabolic disorder. To explicate the pathogenesis of human diabetes and its complications such as retinopathy, nephropathy, cardiomyopathy and neuropathy, diabetic models are playing a key role as the prevalence and complication of this disease is increasing worldwide. Despite all the advantages these animals offer for investigating and developing novel and plausible drugs, they possess individual limitations that will also limit the design of new drugs and therapeutic interventions. Hence forth the selection of model is important that it should possess all the characteristics necessary to be of a perfect model that varies depending on the diabetic complications and animal of choice. A model of autoimmunity is generally preferred for studying the type 1 diabetes but for the type 2 diabetes animals that are obese, non-obese, hyperglycemic, insulin resistance and $\beta$-cell resistance are generally employed. Since the experimental animal models differ in their physiological pertinent and are employed to represent the diverse complications of human diabetic patients much care and study is necessary in selecting the appropriate models for each study.

\section{Acknowledgements}

The authors express their sincere thanks to Manonmaniam Sundaranar University, Tirunelveli, India for their support and encouragement which makes the study a successful one.

\section{Authors' contributions}

C.P.D.K.: Proposed the idea, carried out the review process, retrieved the data and wrote the manuscript. D.S.R.: Designed the review, analysed the retrieved data and revised the paper. V.P.K.: Carried out the review process, retrieved data for Tables and revised the paper U.S.: Approved the idea and takes the responsibility for the integrity and accuracy of the present review and revised the paper. All authors read and approved the final manuscript.

\section{Funding}

Not applicable.

\section{Availability of data and materials}

All data associated with the review were mentioned in the Manuscript.

\section{Declarations}

\section{Competing interests}

Authors declare that they have no conflict of interest.

Received: 4 June 2021 Accepted: 13 August 2021

Published online: 24 August 2021

\footnotetext{
References

1. Unnikrishnan R, Anjana RM, Mohan V. Diabetes mellitus and its complications in India. Nat Rev Endocrinol. 2016;12(6):357-70.
}

2. Kharroubi AT, Darwish HM. Diabetes mellitus: the epidemic of the century. World J Diabetes. 2015;6(6):850-67.

3. Tabish SA. Is diabetes becoming the biggest epidemic of the twentyfirst century? Int J Health Sci (Qassim) . 2007;1(2):v-viii.

4. Rayburn WF. Diagnosis and classification of diabetes mellitus: highlights from the American Diabetes Association. J Reprod Med. 1997:42(9):585-6.

5. Barnett R. Type 1 diabetes. Lancet. 2018;391(10117):195.

6. Tomita T. Apoptosis of pancreatic $\beta$-cells in Type 1 diabetes. Bosn J Basic Med Sci. 2017;17(3):183-93.

7. Atkinson MA. The pathogenesis and natural history of type 1 diabetes. Cold Spring Harbor Perspect Med. 2012;2(11):a007641.

8. Olokoba AB, Obateru OA, Olokoba LB. Type 2 diabetes mellitus: a review of current trends. Oman Med J. 2012;27(4):269-73.

9. Wu Y, Ding Y, Tanaka Y, Zhang W. Risk factors contributing to type 2 diabetes and recent advances in the treatment and prevention. Int J Med Sci. 2014;11(11):1185-200.

10. Kampmann U, Madsen LR, Skajaa GO, Iversen DS, Moeller N, Ovesen P. Gestational diabetes: a clinical update. World J Diabetes. 2015;6(8):1065-72.

11. King AJ. The use of animal models in diabetes research. Br J Pharmacol. 2012;166(3):877-94.

12. Rewers M, Ludvigsson J. Environmental risk factors for type 1 diabetes. Lancet. 2016;387(10035):2340-8.

13. Ndisang JF, Vannacci A, Rastogi S. Insulin resistance, type 1 and type 2 diabetes, and related complications 2017. J Diabetes Res. 2017;2017:1478294.

14. Al-Goblan AS, Al-Alfi MA, Khan MZ. Mechanism linking diabetes mellitus and obesity. Diabetes Metab Syndr Obes. 2014;7:587-91.

15. Mugharbel KM, Al-Mansouri MA. Prevalence of obesity among type 2 diabetic patients in Al-khobar primary health care centers. J Family Community Med. 2003;10(2):49-53.

16. Ewald N, Hardt PD. Diagnosis and treatment of diabetes mellitus in chronic pancreatitis. World J Gastroenterol. 2013;19(42):7276-81.

17. Prasad RB, Groop L. Genetics of type 2 diabetes-pitfalls and possibilities. Genes. 2015;6(1):87-123.

18. Deshpande AD, Harris-Hayes M, Schootman M. Epidemiology of diabetes and diabetes-related complications. Phys Ther. 2008;88(11):1254-64.

19. Ramachandran A, Snehalatha C, Shetty AS, Nanditha A. Trends in prevalence of diabetes in Asian countries. World J Diabetes. 2012;3(6):110-7.

20. Kaveeshwar SA, Cornwall J. The current state of diabetes mellitus in India. Australas Med J. 2014;7(1):45-8.

21. Yesudian CA, Grepstad M, Visintin E, Ferrario A. The economic burden of diabetes in India: a review of the literature. Global Health. 2014;10:80.

22. Ogurtsova K, da Rocha Fernandes JD, Huang Y, Linnenkamp U, Guariguata L, Cho NH, et al. IDF Diabetes Atlas: global estimates for the prevalence of diabetes for 2015 and 2040. Diabetes Res Clin Pract. 2017;128:40-50.

23. Bommer C, Heesemann E, Sagalova V, Manne-Goehler J, Atun R, Bärnighausen T, et al. The global economic burden of diabetes in adults aged 20-79 years: a cost-of-illness study. Lancet Diabetes Endocrinol. 2017;5(6):423-30.

24. Roep BO, Atkinson M. Animal models have little to teach us about type 1 diabetes: 1 . In support of this proposal. Diabetologia. 2004;47(10):1650-6.

25. Arndt $T$, Jörns $A$, Weiss $H$, Tiedge $M$, Hedrich $H J$, Lenzen $S$, et al. A variable $\mathrm{CD}^{+} \mathrm{T}$-cell frequency in peripheral blood lymphocytes associated with type 1 diabetes mellitus development in the LEW.1AR1-iddm rat. PLOS ONE. 2013:8(5):e64305.

26. Graham ML, Schuurman HJ. Validity of animal models of type 1 diabetes, and strategies to enhance their utility in translational research. Eur J Pharmacol. 2015;759:221-30.

27. Kumar S, Singh R, Vasudeva N, Sharma S. Acute and chronic animal models for the evaluation of anti-diabetic agents. Cardiovasc Diabetol. 2012;11:9.

28. Chatzigeorgiou A, Halapas A, Kalafatakis K, Kamper E. The use of animal models in the study of diabetes mellitus. Vivo. 2009;23(2):245-58.

29. Vieira R, Souto SB, Sánchez-López E, Machado AL, Severino P, Jose S, et al. Sugar-lowering drugs for type 2 diabetes mellitus and metabolic syndrome-strategies for in vivo administration: part-II. J Clin Med. 2019;8(9):1332. 
30. Rees DA, Alcolado JC. Animal models of diabetes mellitus. Diabetes Med. 2005;22(4):359-70.

31. Perlman RL. Mouse models of human disease: an evolutionary perspective. Evol Med Public Health. 2016;2016(1):170-6.

32. Peltonen L, McKusick VA. Genomics and medicine. Dissecting human disease in the postgenomic era. Science. 2001;291(5507):1224-9.

33. Heydemann A. An Overview of Murine High Fat Diet as a Model for Type 2 Diabetes Mellitus. J Diabetes Res. 2016;2016:2902351.

34. Islam MS, du Loots T. Experimental rodent models of type 2 diabetes: a review. Methods Find Exp Clin Pharmacol. 2009;31(4):249-61.

35. Iannaccone PM, Jacob HJ. Rats! Dis Model Mech. 2009;2(5-6):206-10.

36. Bryda EC. The Mighty Mouse: the impact of rodents on advances in biomedical research. Mo Med. 2013;110(3):207-11.

37. Skovsø S. Modeling type 2 diabetes in rats using high fat diet and streptozotocin. J Diabetes Investig. 2014;5(4):349-58.

38. Sharma P, Garg A, Garg S, Singh V. Animal model used for experimental study of diabetes mellitus: an overview. Asian J Biomat Res. 2016;2:99-110.

39. Federiuk IF, Casey HM, Quinn MJ, Wood MD, Ward WK. Induction of type-1 diabetes mellitus in laboratory rats by use of alloxan: route of administration, pitfalls, and insulin treatment. Comp Med. 2004;54(3):252-7.

40. Ighodaro OM, Adeosun AM, Akinloye OA. Alloxan-induced diabetes, a common model for evaluating the glycemic-control potential of therapeutic compounds and plants extracts in experimental studies. Medicina (Kaunas). 2017;53(6):365-74.

41. Rohilla A, Ali S. Alloxan induced diabetes: mechanisms and effects. Int J Res Pharm Biomed Sci. 2012;3(2):819-23.

42. Lenzen S. The mechanisms of alloxan- and streptozotocin-induced diabetes. Diabetologia. 2008;51(2):216-26.

43. Katoh M, Sakurai K, Fujimoto Y. Alloxan radical-induced generation of reactive oxygen species in the reaction system of alloxan with ascorbate. Yakugaku Zasshi. 2002;122(10):831-9.

44. Szkudelski T. The mechanism of alloxan and streptozotocin action in B cells of the rat pancreas. Physiol Res. 2001;50(6):537-46.

45. Eileen DM. Inhibition of DNA repair as a means of increasing the antitumor activity of DNA reactive agents. Adv Drug Deliv Rev. 1997;26(2-3):105-18.

46. Wu J, Yan LJ. Streptozotocin-induced type 1 diabetes in rodents as a model for studying mitochondrial mechanisms of diabetic $\beta$ cell glucotoxicity. Diabetes Metab Syndr Obes. 2015;8:181-8.

47. Rakieten N, Rakieten ML, Nadkarni MR. Studies on the diabetogenic action of streptozotocin (NSC-37917). Cancer Chemother Rep. 1963;29:91-8

48. Rerup CC. Drugs producing diabetes through damage of the insulin secreting cells. Pharmacol Rev. 1970;22(4):485-518.

49. Eleazu CO, Eleazu KC, Chukwuma S, Essien UN. Review of the mechanism of cell death resulting from streptozotocin challenge in experimental animals, its practical use and potential risk to humans. J Diabetes Metab Disord. 2013;12(1):60.

50. Ventura-Sobrevilla J, Boone-Villa VD, Aguilar CN, Román-Ramos R, Vega-Avila E, Campos-Sepúlveda E, et al. Effect of varying dose and administration of streptozotocin on blood sugar in male CD1 mice. Proc West Pharmacol Soc. 2011;54:5-9.

51. Graham ML, Janecek JL, Kittredge JA, Hering BJ, Schuurman HJ. The streptozotocin-induced diabetic nude mouse model: differences between animals from different sources. Comp Med. 2011;61(4):356-60.

52. Dufrane D, van Steenberghe M, Guiot Y, Goebbels RM, Saliez A, Gianello P. Streptozotocin-induced diabetes in large animals (pigs/primates): role of GLUT2 transporter and beta-cell plasticity. Transplantation. 2006;81(1):36-45.

53. Elsner M, Guldbakke B, Tiedge M, Munday R, Lenzen S. Relative importance of transport and alkylation for pancreatic beta-cell toxicity of streptozotocin. Diabetologia. 2000;43(12):1528-33.

54. Paik SG, Fleischer N, Shin SI. Insulin-dependent diabetes mellitus induced by subdiabetogenic doses of streptozotocin: obligatory role of cell-mediated autoimmune processes. Proc Natl Acad Sci U S A. 1980;77(10):6129-33.

55. Ellis TM, Atkinson MA. The clinical significance of an autoimmune response against glutamic acid decarboxylase. Nat Med. 1996;2(2):148-53.
56. Kanaani J, Diacovo MJ, El-Husseini Ael D, Bredt DS, Baekkeskov S. Palmitoylation controls trafficking of GAD65 from Golgi membranes to axonspecific endosomes and a Rab5a-dependent pathway to presynaptic clusters. J Cell Sci. 2004;117(Pt 10):2001-13.

57. Deeds MC, Anderson JM, Armstrong AS, Gastineau DA, Hiddinga HJ, Jahangir A, et al. Single dose streptozotocin-induced diabetes: considerations for study design in islet transplantation models. Lab Anim. 2011;45(3):131-40.

58. Furman BL. Streptozotocin-induced diabetic models in mice and rats. Curr Protoc Pharmacol. 2015;70:5.47.1-5.47.20.

59. Thayer TC, Wilson SB, Mathews CE. Use of nonobese diabetic mice to understand human type 1 diabetes. Endocrinol Metab Clin N Am. 2010;39(3):541-61.

60. Pearson JA, Wong FS, Wen L. The importance of the Non Obese Diabetic (NOD) mouse model in autoimmune diabetes. J Autoimmun. 2016:66:76-88.

61. Makino S, Kunimoto K, Muraoka Y, Mizushima Y, Katagiri K, Tochino Y. Breeding of a non-obese, diabetic strain of mice. Jikken Dobutsu. 1980;29(1):1-13.

62. Mathews CE. Utility of murine models for the study of spontaneous autoimmune type 1 diabetes. Pediatr Diabetes. 2005;6(3):165-77.

63. Wallis RH, Wang K, Marandi L, Hsieh E, Ning T, Chao GY, et al. Type 1 diabetes in the BB rat: a polygenic disease. Diabetes. 2009;58(4):1007-17.

64. Hartoft-Nielsen ML, Rasmussen AK, BockT, Feldt-Rasmussen U, Kaas A, Buschard K. lodine and tri-iodo-thyronine reduce the incidence of type 1 diabetes mellitus in the autoimmune prone BB rats. Autoimmunity. 2009;42(2):131-8

65. Holmberg R, Refai E, Höög A, Crooke RM, Graham M, Olivecrona G, et al. Lowering apolipoprotein CIII delays onset of type 1 diabetes. Proc Natl Acad Sci U S A. 2011;108(26):10685-9.

66. Prins JB, Herberg L, Den Bieman M, van Zutphen LF. Genetic variation within and between lines of diabetes-prone and non-diabetesprone BB rats; allele distribution of 8 protein markers. Lab Anim. 1991;25(3):207-11.

67. Mordes JP, Bortell R, Blankenhorn EP, Rossini AA, Greiner DL. Rat models of type 1 diabetes: genetics, environment, and autoimmunity. ILAR J. 2004;45(3):278-91.

68. Yokoi N, Namae M, Fuse M, Wang HY, Hirata T, Seino S, et al. Establishment and characterization of the Komeda diabetes-prone rat as a segregating inbred strain. Exp Anim. 2003;52(4):295-301.

69. Yokoi N, Hayashi C, Fujiwara Y, Wang HY, Seino S. Genetic reconstitution of autoimmune type 1 diabetes with two major susceptibility genes in the rat. Diabetes. 2007;56(2):506-12.

70. Komeda K, Noda M, Terao K, Kuzuya N, Kanazawa M, Kanazawa Y. Establishment of two substrains, diabetes-prone and non-diabetic, from Long-Evans Tokushima Lean (LETL) rats. Endocr J. 1998;45(6):737-44.

71. Yokoi N, Kanazawa M, Kitada K, Tanaka A, Kanazawa Y, Suda S, et al. A non-MHC locus essential for autoimmune type I diabetes in the Komeda Diabetes-Prone rat. J Clin Invest. 1997;100(8):2015-21.

72. Yokoi N, Komeda K, Wang HY, Yano H, Kitada K, Saitoh Y, et al. Cblb is a major susceptibility gene for rat type 1 diabetes mellitus. Nat Genet. 2002;31(4):391-4.

73. Natori T, Kawano K. The LETL rat: a model for IDDM without lymphopenia. ILAR J. 1993;35(1):15-8.

74. Kawano K, Hirashima T, Mori S, Saitoh Y, Kurosumi M, Natori T. New inbred strain of Long-Evans Tokushima lean rats with IDDM without lymphopenia. Diabetes. 1991;40(11):1375-81.

75. Ishida K, Mizuno A, Min Z, Sano T, Shima K. Which is the primary etiologic event in Otsuka Long-Evans Tokushima Fatty rats, a model of spontaneous non-insulin-dependent diabetes mellitus, insulin resistance, or impaired insulin secretion? Metabolism. 1995;44(7):940-5.

76. Al-Awar A, Kupai K, Veszelka M, Szücs G, Attieh Z, Murlasits Z, et al. Experimental diabetes mellitus in different animal models. J Diabetes Res. 2016:2016:9051426

77. Lenzen S, Tiedge M, Elsner M, Lortz S, Weiss H, Jörns A, et al. The LEW.1AR1/Ztm-iddm rat: a new model of spontaneous insulin-dependent diabetes mellitus. Diabetologia. 2001;44(9):1189-96.

78. Jörns A, Günther A, Hedrich HJ, Wedekind D, Tiedge M, Lenzen S. Immune cell infiltration, cytokine expression, and beta-cell apoptosis during the development of type 1 diabetes in the spontaneously diabetic LEW.1AR1/Ztm-iddm rat. Diabetes. 2005;54(7):2041-52. 
79. Mordes JP, Guberski DL, Leif JH, Woda BA, Flanagan JF, Greiner DL, et al. LEW.1WR1 rats develop autoimmune diabetes spontaneously and in response to environmental perturbation. Diabetes. 2005;54(9):2727-33.

80. Arndt T, Jörns A, Hedrich HJ, Lenzen S, Wedekind D. Variable immune cell frequencies in peripheral blood of LEW.1AR1-iddm rats over time compared to other congenic LEW strains. Clin Exp Immunol. 2014;177(1):168-78.

81. Weiss H, Bleich A, Hedrich HJ, Kölsch B, Elsner M, Jörns A, et al. Genetic analysis of the LEW.1AR1-iddm rat: an animal model for spontaneous diabetes mellitus. Mamm Genome. 2005;16(6):432-41.

82. Azushima K, Gurley SB, Coffman TM. Modelling diabetic nephropathy in mice. Nat Rev Nephrol. 2018;14(1):48-56.

83. Kong LL, Wu H, Cui WP, Zhou WH, Luo P, Sun J, et al. Advances in murine models of diabetic nephropathy. J Diabetes Res. 2013;2013:797548.

84. Todd JA. Intolerable secretion and diabetes in tolerant transgenic mice, revisited. Nat Genet. 2016:48(5):476-7.

85. Goto Y, Kakizaki M, Masaki N. Production of spontaneous diabetic rats by repetition of selective breeding. Tohoku J Exp Med. 1976;119(1):85-90.

86. Movassat J, Calderari S, Fernández E, Martín MA, Escrivá F, Plachot C, et al. Type 2 diabetes - a matter of failing beta-cell neogenesis? Clues from the GK rat model. Diabetes Obes Metab. 2007;9(Suppl 2):187-95

87. Portha B. Programmed disorders of beta-cell development and function as one cause for type 2 diabetes? The GK rat paradigm. Diabetes Metab Res Rev. 2005;21(6):495-504.

88. Portha B, Lacraz G, Kergoat M, Homo-Delarche F, Giroix MH, Bailbé D, et al. The GK rat beta-cell: a prototype for the diseased human beta-cell in type 2 diabetes? Mol Cell Endocrinol. 2009;297(1-2):73-85.

89. Portha B, Giroix MH, Tourrel-Cuzin C, Le-Stunff H, Movassat J. The GK rat: a prototype for the study of non-overweight type 2 diabetes. Methods Mol Biol. 2012;933:125-59.

90. Nie J, Xue B, Sukumaran S, Jusko WJ, Dubois DC, Almon RR. Differential muscle gene expression as a function of disease progression in GotoKakizaki diabetic rats. Mol Cell Endocrinol. 2011;338(1-2):10-7.

91. Xue B, Sukumaran S, Nie J, Jusko WJ, Dubois DC, Almon RR. Adipose tissue deficiency and chronic inflammation in diabetic Goto-Kakizaki rats. PLOS ONE. 2011;6(2):e17386

92. Garnett KE, Chapman P, Chambers JA, Waddell ID, Boam DS. Differential gene expression between Zucker Fatty rats and Zucker Diabetic Fatty rats: a potential role for the immediate-early gene Egr-1 in regulation of beta cell proliferation. J Mol Endocrinol. 2005;35(1):13-25.

93. Srinivasan K, Ramarao P. Animal models in type 2 diabetes research: an overview. Indian J Med Res. 2007;125(3):451-72.

94. Phillips MS, Liu Q, Hammond HA, Dugan V, Hey PJ, Caskey CJ, et al. Leptin receptor missense mutation in the fatty Zucker rat. Nat Genet. 1996:13(1):18-9.

95. Chen D, Wang MW. Development and application of rodent models for type 2 diabetes. Diabetes Obes Metab. 2005;7(4):307-17.

96. Slieker LJ, Sundell KL, Heath WF, Osborne HE, Bue J, Manetta J, et al. Glucose transporter levels in tissues of spontaneously diabetic Zucker fa/fa rat (ZDF/drt) and viable yellow mouse (Avy/a). Diabetes. 1992;41(2):187-93.

97. Wexler BC, lams SG, McMurtry JP. Pathophysiological differences between obese and non-obese spontaneously hypertensive rats. $\mathrm{Br} J$ Exp Pathol. 1980;61(2):195-207.

98. Koletsky S. Obese spontaneously hypertensive rats-a model for study of atherosclerosis. Exp Mol Pathol. 1973;19(1):53-60.

99. Tarrés MC, Martinez SM, Montenegro S, Llorens A, Picena JC, Naves A. The eSS rat. A model of non-insulin-dependent human diabetes. Am $J$ Pathol. 1992;141(3):761-3.

100. Gómez Dumm CL, Semino MC, Gagliardino JJ. Sequential morphological changes in pancreatic islets of spontaneously diabetic rats. Pancreas. 1990;5(5):533-9.

101. Hummel KP, Dickie MM, Coleman DL. Diabetes, a new mutation in the mouse. Science. 1966;153(3740):1127-8.

102. Chen W, Zhou XB, Liu HY, Xu C, Wang LL, Li S. P633H, a novel dual agonist at peroxisome proliferator-activated receptors alpha and gamma, with different anti-diabetic effects in $\mathrm{db} / \mathrm{db}$ and $\mathrm{KK}$-Ay mice. $\mathrm{Br}$ J Pharmacol. 2009;157(5):724-35.

103. Ikeda H. KK mouse. Diabetes Res Clin Pract. 1994;24(Suppl):S313-6.
104. Berndt A, Sundberg BA, Silva KA, Kennedy VE, Richardson MA, Li Q, et al. Phenotypic characterization of the KK/HIJ inbred mouse strain. Vet Pathol. 2014:51(4):846-57.

105. Bleisch VR, Mayer J, Dickie MM. Familial diabetes mellitus in mice, associated with insulin resistance, obesity, and hyperplasia of the islands of langerhans. Am J Pathol. 1952;28(3):369-85.

106. Halaas JL, Gajiwala KS, Maffei M, Cohen SL, Chait BT, Rabinowitz D, et al. Weight-reducing effects of the plasma protein encoded by the obese gene. Science. 1995;269(5223):543-6.

107. Leahy JL, Bonner-Weir S, Weir GC. Minimal chronic hyperglycemia is a critical determinant of impaired insulin secretion after an incomplete pancreatectomy. J Clin Invest. 1988;81(5):1407-14.

108. Bonner-Weir S, Trent DF, Weir GC. Partial pancreatectomy in the rat and subsequent defect in glucose-induced insulin release. J Clin Invest. 1983;71(6):1544-53.

109. Yoon JW, London WT, Curfman BL, Brown RL, Notkins AL. Coxsackie virus $B 4$ produces transient diabetes in nonhuman primates. Diabetes. 1986;35(6):712-6.

110. Guberski DL, Thomas VA, Shek WR, Like AA, Handler ES, Rossini AA, et al. Induction of type I diabetes by Kilham's rat virus in diabetes-resistant BB/Wor rats. Science. 1991;254(5034):1010-3.

111. Baek HS, Yoon JW. Direct involvement of macrophages in destruction of beta-cells leading to development of diabetes in virus-infected mice. Diabetes. 1991;40(12):1586-97.

112. Yoon JW, Austin M, Onodera T, Notkins AL. Isolation of a virus from the pancreas of a child with diabetic ketoacidosis. N Engl J Med. 1979;300(21):1173-9.

113. Utsugi T, Kanda T, Tajima Y, Tomono S, Suzuki T, Murata K, et al. A new animal model of non-insulin-dependent diabetes mellitus induced by the NDK25 variant of encephalomyocarditis virus. Diabetes Res. 1992:20(4):109-19.

114. Meier H, Yerganian G. Spontaneous hereditary diabetes mellitus in the Chinese hamster (Cricetulus griseus). III. Maintenance of a diabetic hamster colony with the aid of hypoglycemic therapy. Diabetes. 1961:10:19-21.

115. Wise PH, Weir BJ, Hime JM, Forrest E. The diabetic syndrome in the tucotuco (Ctenomys talarum). Diabetologia. 1972;8(3):165-72.

116. Kane JD, Steinbach TJ, Sturdivant RX, Burks RE. Sex-associated effects on hematologic and serum chemistry analytes in sand rats (Psammomys obesus). J Am Assoc Lab Anim Sci. 2012:51(6):769-74.

117. Ziv E, Shafrir E, Kalman R, Galer S, Bar-On H. Changing pattern of prevalence of insulin resistance in Psammomys obesus, a model of nutritionally induced type 2 diabetes. Metabolism. 1999;48(12):1549-54.

118. Marquié G, Hadjiisky P, Arnaud O, Duhault J. Development of macroangiopathy in sand rats (Psammomys obesus), an animal model of non-insulin-dependent diabetes mellitus: effect of gliclazide. Am J Med. 1991;90(6a):55s-61s.

119. Matveyenko AV, Butler PC. Islet amyloid polypeptide (IAPP) transgenic rodents as models for type 2 diabetes. ILAR J. 2006;47(3):225-33.

120. Shafrir E, Ziv E, Kalman R. Nutritionally induced diabetes in desert rodents as models of type 2 diabetes: Acomys cahirinus (spiny mice) and Psammomys obesus (desert gerbil). ILAR J. 2006;47(3):212-24.

121. Meng $X$, Zhu F, Chen K. Silkworm: a promising model organism in life science. J Insect Sci. 2017;17(5):97.

122. International Silkworm Genome Consortium. The genome of a lepidopteran model insect, the silkworm Bombyx mori. Insect Biochem Mol Biol. 2008:38(12):1036-45.

123. Zhang X, Xue R, Cao G, Pan Z, Zheng X, Gong C. Silkworms can be used as an animal model to screen and evaluate gouty therapeutic drugs. J Insect Sci. 2012;12:4.

124. Phillips RW, Panepinto LM, Spangler R, Westmoreland N. Yucatan miniature swine as a model for the study of human diabetes mellitus. Diabetes. 1982;31(Suppl 1 Pt 2):30-6.

125. Boullion RD, Mokelke EA, Wamhoff BR, Otis CR, Wenzel J, Dixon JL, et al. Porcine model of diabetic dyslipidemia: insulin and feed algorithms for mimicking diabetes mellitus in humans. Comp Med. 2003;53(1):42-52.

126. Hansen BC, Bodkin NL. Heterogeneity of insulin responses: phases leading to type 2 (non-insulin-dependent) diabetes mellitus in the rhesus monkey. Diabetologia. 1986;29(10):713-9.

127. Bremer AA, Stanhope KL, Graham JL, Cummings BP, Wang W, Saville $B R$, et al. Fructose-fed rhesus monkeys: a nonhuman primate model of 
insulin resistance, metabolic syndrome, and type 2 diabetes. Clin Trans| Sci. 2011;4(4):243-52.

128. Zhu H, Yu L, He Y, Wang B. Nonhuman primate models of type 1 diabetes mellitus for islet transplantation. J Diabetes Res. 2014;2014:785948.

129. Den Broeder MJ, Kopylova VA, Kamminga LM, Legler J. Zebrafish as a model to study the role of peroxisome proliferating-activated receptors in Adipogenesis and obesity. PPAR Res. 2015;2015:358029.

130. Lieschke GJ, Currie PD. Animal models of human disease: zebrafish swim into view. Nat Rev Genet. 2007:8(5):353-67.

131. Oka T, Nishimura Y, Zang L, Hirano M, Shimada Y, Wang Z, et al. Dietinduced obesity in zebrafish shares common pathophysiological pathways with mammalian obesity. BMC Physiol. 2010;10:21.

132. Teame T, Zhang Z, Ran C, Zhang H, Yang Y, Ding Q, et al. The use of zebrafish (Danio rerio) as biomedical models. Anim Front. 2019;9(3):68-77.

133. Papatheodorou K, Banach M, Bekiari E, Rizzo M, Edmonds M. Complications of diabetes 2017. J Diabetes Res. 2018;2018:3086167.

134. Giacco F, Brownlee M. Oxidative stress and diabetic complications. Circ Res. 2010;107(9):1058-70.

135. Hage Hassan R, Bourron O, Hajduch E. Defect of insulin signal in peripheral tissues: important role of ceramide. World J Diabetes. 2014;5(3):244-57.

136. Chawla A, Chawla R, Jaggi S. Microvasular and macrovascular complications in diabetes mellitus: distinct or continuum? Indian J Endocrinol Metab. 2016;20(4):546-51.

137. Bansal V, Kalita J, Misra UK. Diabetic neuropathy. Postgrad Med J. 2006;82(964):95-100

138. Yagihashi S, Mizukami H, Sugimoto K. Mechanism of diabetic neuropathy: where are we now and where to go? J Diabetes Investig. 2011;2(1):18-32

139. Jakobsen J, Lundbaek K. Neuropathy in experimental diabetes: an animal model. Br Med J. 1976;2(6030):278-9.

140. O'Brien PD, Sakowski SA, Feldman EL. Mouse models of diabetic neuropathy. ILARJ. 2014;54(3):259-72.

141. Muthuraman A, Ramesh M, Sood S. Development of animal model for vasculatic neuropathy: induction by ischemic-reperfusion in the rat femoral artery. J Neurosci Methods. 2010;186(2):215-21.

142. Kennedy WR, Quick DC, Miyoshi T, Gerritsen GC. Peripheral neurology of the diabetic Chinese hamster. Diabetologia. 1982;23(5):445-51.

143. Cornblath DR, Hillman MA, Striffler JS, Herman CN, Hansen BC. Peripheral neuropathy in diabetic monkeys. Diabetes. 1989;38(11):1365-70.

144. Singh VP, Bali A, Singh N, Jaggi AS. Advanced glycation end products and diabetic complications. Korean J Physiol Pharmacol. 2014;18(1):1-14

145. Reddy MA, Tak Park J, Natarajan R. Epigenetic modifications in the pathogenesis of diabetic nephropathy. Semin Nephrol. 2013;33(4):341-53.

146. Watanabe Y, Itoh Y, Yoshida F, Koh N, Tamai H, Fukatsu A, et al. Unique glomerular lesion with spontaneous lipid deposition in glomerular capillary lumina in the NON strain of mice. Nephron. 1991;58(2):210-8.

147. Alpers CE, Hudkins KL. Mouse models of diabetic nephropathy. Curr Opin Nephrol Hypertens. 2011;20(3):278-84.

148. Janssen U, Riley SG, Vassiliadou A, Floege J, Phillips AO. Hypertension superimposed on type II diabetes in Goto Kakizaki rats induces progressive nephropathy. Kidney Int. 2003;63(6):2162-70.

149. Kitada M, Ogura Y, Koya D. Rodent models of diabetic nephropathy: their utility and limitations. Int J Nephrol Renovasc Dis. 2016;9:279-90.

150. Intine RV, Olsen AS, Sarras MP Jr. A zebrafish model of diabetes mellitus and metabolic memory. JVis Exp. 2013;72:e50232.

151. Cade WT. Diabetes-related microvascular and macrovascular diseases in the physical therapy setting. Phys Ther. 2008;88(11):1322-35.

152. Wang W, Lo ACY. Diabetic retinopathy: pathophysiology and treatments. Int J Mol Sci. 2018;19(6):1816.
153. Olivares AM, Althoff K, Chen GF, Wu S, Morrisson MA, DeAngelis MM, et al. Animal models of diabetic retinopathy. Curr Diab Rep. 2017:17(10):93.

154. Cai X, McGinnis JF. Diabetic retinopathy: animal models, therapies, and perspectives. J Diabetes Res. 2016;2016:3789217.

155. Lai AKW, Lo ACY. Animal models of diabetic retinopathy: summary and comparison. J Diabetes Res. 2013:2013:106594.

156. Heckler K, Kroll J. Zebrafish as a model for the study of microvascular complications of diabetes and their mechanisms. Int J Mol Sci. 2017;18(9):2002.

157. Athithan L, Gulsin GS, McCann GP, Levelt E. Diabetic cardiomyopathy: pathophysiology, theories and evidence to date. World J Diabetes. 2019;10(10):490-510.

158. Bhatti R, Sharma S, Singh J, Ishar MP. Ameliorative effect of Aegle marmelos leaf extract on early stage alloxan-induced diabetic cardiomyopathy in rats. Pharm Biol. 2011;49(11):1137-43.

159. Rodrigues B, McNeill JH. Cardiac dysfunction in isolated perfused hearts from spontaneously diabetic BB rats. Can J Physiol Pharmacol. 1990;68(4):514-8.

160. Bellinger DA, Merricks EP, Nichols TC. Swine models of type 2 diabetes mellitus: insulin resistance, glucose tolerance, and cardiovascular complications. ILARJ. 2006;47(3):243-58.

161. Mizushige K, Yao L, Noma T, Kiyomoto H, Yu Y, Hosomi N, et al. Alteration in left ventricular diastolic filling and accumulation of myocardial collagen at insulin-resistant prediabetic stage of a type II diabetic rat model. Circulation. 2000;101(8):899-907.

162. Ares-Carrasco S, Picatoste B, Benito-Martín A, Zubiri I, Sanz AB, SánchezNiño MD, et al. Myocardial fibrosis and apoptosis, but not inflammation, are present in long-term experimental diabetes. Am J Physiol Heart Circ Physiol. 2009;297(6):H2109-19.

163. Picatoste B, Ramírez E, Caro-Vadillo A, Iborra C, Ares-Carrasco S, Egido J, et al. Sitagliptin reduces cardiac apoptosis, hypertrophy and fibrosis primarily by insulin-dependent mechanisms in experimental type-II diabetes. Potential roles of GLP-1 isoforms. PLoS ONE. 2013;8(10):e78330.

164. Gvazava IG, Rogovaya OS, Borisov MA, Vorotelyak EA, Vasiliev AV. Pathogenesis of type 1 diabetes mellitus and rodent experimental models. Acta Naturae. 2018;10(1):24-33.

165. Wang B, Chandrasekera PC, Pippin JJ. Leptin- and leptin receptordeficient rodent models: relevance for human type 2 diabetes. Curr Diabetes Rev. 2014;10(2):131-45.

166. Wang YW, Sun GD, Sun J, Liu SJ, Wang J, Xu XH, et al. Spontaneous type 2 diabetic rodent models. J Diabetes Res. 2013:2013:401723.

167. Lutz TA, Woods SC. Overview of animal models of obesity. Curr Protoc Pharmacol. 2012;58(1):5-61.

168. Tomino Y. Lessons from the KK-Ay mouse, a spontaneous animal model for the treatment of human type 2 diabetic nephropathy. Nephrourol Mon. 2012:4(3):524-9.

169. Chen C, Cohrs CM, Stertmann J, Bozsak R, Speier S. Human beta cell mass and function in diabetes: recent advances in knowledge and technologies to understand disease pathogenesis. Mol Metab. 2017:6(9):943-57.

170. Horwitz MS, Bradley LM, Harbertson J, Krahl T, Lee J, Sarvetnick N. Diabetes induced by Coxsackie virus: initiation by bystander damage and not molecular mimicry. Nat Med. 1998;4(7):781-5.

171. Filippi $C M$, von Herrath MG. Viral trigger for type 1 diabetes: pros and cons. Diabetes. 2008;57(11):2863-71.

\section{Publisher's Note}

Springer Nature remains neutral with regard to jurisdictional claims in published maps and institutional affiliations. 